\title{
The potential by-product of Indonesian superior native chicken
}

\author{
Nurul Agustini, Totok B Julianto, I Putu Cakra Putra Adnyana, and Luh Gde Sri Astiti* \\ Assessment Institute for Agricultural Technology West Nusa Tenggara, Jalan Raya Peninjauan \\ Narmada Lombok 83371 Indonesia
}

\begin{abstract}
The IAARD has develop KUB-1, Sensi-1 Agrinak chickens and their cross breeding as a source of alternative protein. This research aimed to gain more data and information related to by-product potencies of farming this chicken. The sample used were 210 chickenswhich was treated carefully. The data was taken at 6-12 weeks of slaughtered-age. The observed variables were the weight of blood, feather and internal organs respectively. The $3 \times 7$ complete randomized factorial designof experiment was used. The data was analysed by means of the analysis of variance using of GenStat software. Furthermore, the results show that KUB-1 chicken had more by-product potential such as blood and internal organ among thechickens being investigated and was significantly affected by the slaughter-age $(\mathrm{P}<0.01)$. The percentage of internal organs to the living weight of the superior native chickens was as much as $17 \%$ greater than that of native chickens. Meanwhile, by-product of feathers of superior native chicken was as much weight as broiler's feathers. The slaughter-age has no significant effect on feathers by-product of superior native chicken $(\mathrm{P}>0.05)$. In the other hand the potency of economic value of internal organ per kilogramwas between Rp. $19.000-27.000$ which was affected by the weight of internal organ.
\end{abstract}

\section{Introduction}

The increase in population and their income will greatly affect the increase in the need for animal protein. The availability of abundant chicken meat throughout the year has become one of the main sources of animal protein in Indonesia. Increased consumption of chicken meat has reach $10-15 \%$ per year, which were in 2013 alone the total consumption of broiler chickens reached 2.2 billion chickens [1]. In the other hand, as much as $12.33 \%$ of the total of national consumption was the contribution of native chickens. Furthermore, if it is assumed that the protein consumption of one person was $80 \mathrm{~g}$ /day, it takes as much as 1.46 million tons of chicken meat which are equivalent to aproximatelly 7.30 billion domestic chickens per year [2].

The ever increasing demand for native chicken meat has provided not only a promising business opportunities but also drive futher develompent of its farming supportsystems. In recent years, native chicken has been in great demand because of its specific flavor.

\footnotetext{
* Corresponding author: luhde astiti@yahoo.com
} 
However, its low productivity has resulted in a shortage stock, which has made its price has been two times higher than the price of broiler. Meanwhile, the price and its availability in the market were the main considerations that determine whether consumers will consume or not that native chicken [3-5].

Various efforts have been made in order to increase the productivity of native chickens not only to accelerate the production of meat but also to increase the number of eggs. The development of superior native chickens was one of the efforts among others. The superior native chicken that has been developed was the superior native chicken of the Indonesian Agency for Agricultural research and development (KUB-1), selected Sentul chickens (Sensi-1 Agrinak) and cross-breeding of KUB-1 and Sensi-1 Agrinak chickens. The rapid development of the native chicken farming was of course inseparable from the production of its by-products, such as blood, feathers, and internal organs. Meanwhile, the data and information related to the by-products of superior native chicken farming has still not widely published. This research, therefore, aims to determine the potential of by-products of the superior native chicken produced by the Indonesian Agency for Agricultural research and development (KUB-1), selected Sentul chickens (Sensi-1 Agrinak) as well as their cross-breeding.

\section{Methodology}

There were two hundred and ten (210) un sexing DOC of KUB-1 (Treatment V1), Sensi-1 Agrinak (Treatment V2) and their cross-breeding chickens (Treatment V3) used as samples in this study. The DOC samples were kept and maintain in a brooder cage. After 2 weeks of age, the chickens were moved into three units of postal cages with dimension of 1meter length $\times 1.5$ meters wide that has equipped with food and drinking containers. The feed given was the commercial feed for broiler, meanwhile the drinking water was given ad libitum. All samples were vaccinated and given vitamins according to AIAT West Nusa Tenggara's standard procedure for chickens farming. In this research, the complete randomize of $3 \times 7$ factorial of design of experiment was adopted. The data were taken at the slaughter age of $6,7,8,9,10,11$ and 12 weeks. The variables observed were the weight of blood, feather and internal organ (liver, heart, gizzard, kidney and intestine). The data obtained were then tabulated and analysed using of analysis of variance with the GenStat software.

\section{Results and Discussion}

In this research, the content of protein within the feed given to the chicken based on the nutrition content on the label attached in pack of commercial feed used was $21-23 \%$. This content was much higher than the protein required by the native chickens during its growth period which was $14 \%$ [6]. The protein content in feed that was given to the chicken samples was intended to get optimal production of the chicken. This is in line with [7] which stated that increasing of content of protein in the feed will be able increase the number of the eggs produced. 
Table 1. The average of percentage of by-products from live weight of treated chickens up to 12 weeks of slaughter ingage

\begin{tabular}{|l|r|r|r|}
\hline \multirow{2}{*}{ Indicators } & \multicolumn{3}{|c|}{ Percentage of live weight (\%) } \\
\cline { 2 - 4 } & Treatment V1 & Treatment V2 & \multicolumn{1}{c|}{ Treatment V3 } \\
\hline Blood & 7.72 & 4.35 & 4.98 \\
\hline Feather & 9.56 & 3.83 & 9.60 \\
\hline InternalOrgansbeforecleaning & 13.80 & 13.98 & 12.23 \\
\hline InternalOrgansaftercleaning & 9.27 & 9.32 & 9.42 \\
\hline
\end{tabular}

Based on table 1, it can beseenthat the rank from highest to lowest of the percentage of weight of blood, internal organ and feathers were treatment V1, V2 and V3, respectively. Furthermore, according to the statistical analysis, it shows that the slaughter age of treatment V1 had high significant impact on blood, feather and internal organ weight $(\mathrm{P}$ $<0.01)$. Whereas, in V2 and V3 treatments, the slaughter age had a moderate significant effect on the weight of blood and internal organs $(\mathrm{P}<0.01)$, but had no effect $(\mathrm{P}>0.05)$ on the weight of the feather produced. This shows that the KUB-1 chickens have great potential to produce blood and internal organs which are economically valuable. The percentage of internal organs of the live weight produced by superior native chickens (KUB-1, Sensi-1 Agrinak and their cross-breeding chickens) was 17\% greater than that of native chickens which was $2.44 \%$ [8].

There are so many benefits of by-products of chicken farming. Its by-products contain enzymes, proteins and fats which are biomolecules that can be processed into useful products that are beneficial for health, food nutrition, pharmaceuticals and cosmetics [9].Furthermore, the internalorgans and blood can beutilized as a source of animal and pet food as well as fertilizer [10].The percentage of chicken feathers produced by superior native chickens was as high as broiler's chickens with the range of $4-7 \%$ of body weight [11-12]. This shows that all superior native chickens used in this study have high potential of feathers by-product which are the same as broiler chickens. The use of feather as a duster, shutlecock [13], as well as others have been widely researched for a long time ago. Furthermore, the chicken feathers contain protein that can be used as animal feed for both poultry and ruminants [13-15] and for manufacture of fish pellets [16-17]. Other studies have also shows that chicken feathers are composed of keratin which has light and strong properties as an additional material in paper manufacturing and acoustic wall panel materials $[12,18]$.

Table 2. Economic value of internal organs at farmer and the trader level

\begin{tabular}{|l|r|r|r|}
\hline Economic value of internal organ at farmer & $\begin{array}{c}\text { Treatment } \\
\text { V1 }\end{array}$ & $\begin{array}{c}\text { Treatment } \\
\text { V2 }\end{array}$ & $\begin{array}{c}\text { Treatment } \\
\text { V3 }\end{array}$ \\
\hline Net Selling Price of InternalOrgans $(\mathrm{Rp} /$ chicken $)$ & 2.000 & 2.000 & 2.000 \\
\hline Net Selling Value of InternalOrgans $(\mathrm{Rp} / \mathrm{kg})$ & 20.833 & 22.222 & 19.231 \\
\hline Economic value of internal organ at trader & $\begin{array}{c}\text { Treatment } \\
\text { V1 }\end{array}$ & $\begin{array}{c}\text { Treatment } \\
\text { V2 }\end{array}$ & $\begin{array}{c}\text { Treatment } \\
\text { V3 }\end{array}$ \\
\hline Net Selling Price of InternalOrgans $(\mathrm{Rp} / \mathrm{chicken})$ & 2.500 & 2.500 & 2.500 \\
\hline Net Selling Value of InternalOrgans $(\mathrm{Rp} / \mathrm{kg})$ & 26.042 & 27.778 & 24.038 \\
\hline
\end{tabular}

Based on Table 2, at farmer level as well as trader, the price of internal organs of all chicken's type was similar atRp. 2,000/chicken and 2,500/chicken respectively. The difference in the selling price of internal organs in farmer and trader levels were IDR $500 /$ chicken. If the selling price of internal organs at the farmer level is multiplied by the 
weight of it being produced, the difference in the selling value will be in the range of IDR $19,000 / \mathrm{kg}$ to IDR $22,000 / \mathrm{kg}$. Meanwhile, at the trader level, those differences were within the range of IDR $24,000 / \mathrm{kg}$ to IDR. $27,000 / \mathrm{kg}$. It can be concluded that the economic value of the internal organs of the not influenced by type of chicken, but by the weight of its internal organs.

\section{Conclusions}

The KUB-1 chicken has great potential to produce by-products in the form of blood and internal organs that can be reused. The percentage of internal organs of the live weight produced by superior native chickens was $17 \%$ greater than that of native chickens. The byproduct potential in the form of feathers of superior native chickens was the same as of broiler chickens. The price of internal organ was not influenced by chicken type, but by the weight of its internal organs.

Acknowledgement. Great gratitude is conveyed to the head of the Assessment Institute for Agricultural Technology West Nusa Tenggara for permission to conduct research and Mrs Luh Gde Sri Astiti to supervised and encourage this paper. Last gratitude is also conveyed to the staff who helped conduct this research.

\section{References}

1. Soegiyono. 2013.Permintaan Ayam Ras Broiler Naik 15,8\% di 2013, accessed on 17 Desember 2020. (http://livestockreview.com/permintaan-akan-ayam-ras-broiler-naik158-di-2013).

2. G. Rosita, L N Prawesti, U Fadlilah, $\mathrm{Y}$ LRaynardia, E Nugrahini, JurnalFakultasPertanian UNS. 4,1(2020).

3. D. Wahyuni, L. Purnastuti L, Mustofa, Jurnal Economia.12,1 (2016).

4. Hasriani, Arifin, A APata. Jurnal Agribis. 1,1 (2019).

5. C I Mamuaja, BRorimpandey, EWantasen, S Dalie,Zootec.40,1 (2020).

6. N T Nawawi, Nurrohmah, Ransum Ayam Kampung. (PT Trubus Agrisarana, Surabaya, 2009).

7. C Hidayat, S Iskandar, T Sartika, JITV. 16(2011)

8. Marhayani, Harmoko, TolisIlmiah: Jurnal Penelitian. 1,2(2019)

9. A RSeidavi, HZaker-Esteghamati, C G Scanes, World's Poultry Science Journal, 75,1 (2019)

10. A Lasekan, F A Bakar, D Hashim, Waste Management (2012) http://dx.doi.org/10.1016/j.wasman.2012.08.001

11. M Berebu, I Spiridon. Journal of Analytical and Applied Pyrolysis. 91 (2011).

12. A Asngad, I N Siti, S Siska, Bioeksperimen. 2,1(2016).

13. D Erlita, A Puspitasari, T Isbandi. Reduksi limbah rumah potong ayam (RPA) sebagai alternatif bahan ransum pakan berprotein in Prosiding SNST ke-7 Tahun 2016 Fakultas Teknik Universitas Wahid Hasyim Semarang (2016).

14. Mirnawati, Jurnal Peternakan Indonesia. 11, 3 (2006).

15. E P Sari, I S T Putri, R A Putri, S Imanda, D E Ifidasari, R L Puspitasari, pemanfaatan limbah bulu ayam sebagai pakan ternak ruminansia in Prosiding Seminar Nasional Masyarakat Biodiversiti Indonesia, 20 Desember, Depok, Indonesia (2014).

16. S Huda, Sulhadi, M P Aji, Pembuatan dan karakterisasi pelet ikan dari bulu ayam in Prosiding Seminar Nasional Fisika, Prodi Pendidikan Fisika, Fakultas MIPA, 
Universitas Negeri Jakarta, Indonesia (2016) http://snf-unj.ac.id/kumpulanprosiding/snf2016

17. P I Lestari, Yamtana, B Suwerda, Jurnal Kesehatan Lingkungan. 8,1 (2016)

18. Ansarullah, R Rahim, A Kusno, Potensi limbah bulu ayam menjadi material panel dinding akustik in Prosiding Temu Ilmiah Ikatan Peneliti Lingkungan Binaan Indonesia (IPLBI) Aceh, Indonesia (2017) 